\title{
Performans och text - entextualiseringar av dans och rytmik $i$ idrottsundervisningen i en högstadieklass
}

\author{
Anna-Maija Norberg* \\ Institutionen för humaniora, utbildnings- och samhällsvetenskap, Örebro universitet
}

\begin{abstract}
Sammanfattning
Artikeln, som är en del av en längre etnografisk studie om skrift- och bedömningspraktiker i idrottsämnet, undersöker skriftliga texters roll under ett undervisningsblock i dans och rytmik i en högstadieklass i Sverige. Närmare bestämt undersöks för vilka ändamål skriftbaserade texter används och vad de använda texterna handlar om, det vill säga vilket specifikt ämnesinnehåll som entextualiseras (Bauman \& Briggs, 1990). Därmed fyller artikeln en empirisk lucka i forskningen om literacy i idrott och hälsa. I studien ses literacy som situerade sociala praktiker, vilket innebär att man kan tala om olika "literacies" i olika domäner. Här undersöks literacy i förståelsen skriftbruk i idrott och hälsa med hjälp av begreppen skrifthändelse och skriftpraktik. Resultaten visar att texter används för mångfasetterade syften, så som planering och introduktion av undervisningen, utvärdering och reflektion, kunskapsredovisning och bedömning och som redskap i såväl teoretiska som praktiska undervisningsaktiviteter. Rörelse framstår som det mest frekvent men också det mest nyanserat entextualiserade ämnesinnehållet.
\end{abstract}

\section{Nyckelord: Idrott och hälsa; skriftpraktik; skrifthändelse; entextualisering; literacy}

\begin{abstract}
As part of a longer ethnographic study on literacy and assessment pratices in Physical Education and Health (PEH), this article investigates the functions of written texts in a PEH-class in lower secondary school in Sweden. The paper aims at identifying the purposes and content of texts as part of teachers' and students' actions in PEH-class spaces. It specifically addresses the question of what specific subject content that is entextualized (Bauman \& Briggs, 1990), i.e. lifted out of its interactional setting and recentered as a text in a new setting. In the study, literacy is understood as situated social practice associated with specific domains. In order to investigare the specific literacy in $\mathrm{PEH}$, literacy event and literacy practice are used. The results show that the texts are used for a wide array of purposes such as the planning and introduction of formal instruction, evaluation, reflection, assessment, and as tools for theoretical as well as physical activities. Movement is shown to not only be the most frequently entextualized subject content but also the subject content which is entextualized in the most nuanced ways.
\end{abstract}

\footnotetext{
^Korrespondanse: Anna-Majia Norberg, Institutionen för humaniora, utbildnings- och samhällsvetenskap, Örebro universitet, 70182 Örebro. Epost: anna-maija.norberg@oru.se

(C) 2019 A.-M. Norberg. This is an Open Access article distributed under the terms of the Creative Commons Attribution 4.0 International License (https://creativecommons.org/licenses/by-nc/4.0/), allowing third parties to copy and redistribute the material in any medium or format and to remix, transform, and build upon the material for any purpose, even commercially, provided the original work is properly cited and states its license.

Citation: A.-M. Norberg. "Performans och text - entextualiseringar av dans och rytmik i idrottsundervisningen $i$ en högstadieklass" Nordic Fournal of Literacy Research, Vol. 5(1), 2019, pp. 38-57. http://dx.doi.org/10.23865/njlr.v5.1477
} 
Keywords: Physical education and health; literacy practice; literacy event; entextualization; literacy

Received: November, 2018; Accepted: March, 2019; Published: May, 2019

"Eleverna sitter i en ring på golvet i idrottshallen. Läraren sitter på huk i mitten och
delar ut papper. Han uppmanar eleverna att titta på pappren två och två. 'Jag har fått
in era analyser, Madeleines ser ut såhär. Ni har skrivit namn, ni har skrivit vad låten
heter, ni har tagit ut takterna och ni har skrivit stegen. Och när ni sen visar upp ert
program under de här tre, fyra minuterna och klassen ger er världens största applåd,
så har jag fyllt i den här.' Läraren visar upp bedömningsmallen.” (Fältanteckning
och transkription av videoinspelning, redovisningstillfälle $1,20 / 112017$ )

Händelsen ovan äger rum i samband med att elever i en högstadieklass ska presentera sina uppvärmningsprogram, det vill säga ett slags aerobicspass, som en examination av ett undervisningsblock inom skolämnet idrott och hälsa (hädanefter idrottsämnet eller idrott och hälsa ${ }^{1}$ ). Det är vad David Barton benämner en skrifthändelse, det vill säga en händelse där skrift har en roll (t.ex. Barton, 2007, se nedan). Vi vet att användning av skrift ökar i samhället i stort och även i skolan, men vi vet mindre om vilka konsekvenser detta har för ämnen som traditionellt inte varit textmedierade, exempelvis idrottsämnet (se t.ex. Tholin, 2006; Quennerstedt, 2006; Tolgfors, 2017). Vi vet därmed ganska lite om hur texter används i idrottsämnet och heller inte vilken potential textanvändning har i kunskapsbyggande praktiker i ämnet. I föreliggande studie undersöks hur kunskaper i idrottsämnet entextualiseras (Bauman \& Briggs, 1990, se nedan) genom de skriftpraktiker som förekommer i ämnets undervisningspraktik, något som kan antas ha betydelse för elevernas meningsskapande men också för en grundläggande förändring av själva ämnet.

Bauman och Briggs (1990, s. 73) definierar entextualisering som en process som gör en räcka av språklig produktion till en enhet, en text, som kan lyftas ut ur sitt interaktionella sammanhang, det vill säga decenteras, och senare flyttas som ny text i nya sammanhang, det vill säga recenteras. I föreliggande undersökning anpassas begreppet så att det inte enbart omfattar decentering av språklig produktion utan även av andra flyktiga handlingar som genom entextualiseringsprocesser görs till något påtagligt och fast (jfr Hanell, 2017; se nedan), det vill säga en text förstådd som ett i sammanhanget meningsfullt, sammanhängande yttrande med en början och ett slut (jfr Björkvall, 2009, s. 8).

Att använda texter, exempelvis läsa och skriva dem, är vanligt förekommande aktiviteter i skolan men kanske inget man i första hand förknippar med ämnet idrott och hälsa. Dock har både det ökande skriftbruket i samhället i stort och nya läroplaner i skolan satt fokus på literacy i skolans alla ämnen. Ordet literacy är svårt att översätta till svenska, då det har flera betydelser och då begreppet dessutom under de senaste åren genomgått en betydelseutvidgning till att även inkludera meningsskapande

${ }^{1}$ Ämnet består sedan 1994 års läroplansreform av de två delarna idrott och hälsa. Därmed har ämnets syfte och innehåll också förändrats. 
genom "flyktiga" modaliteter (t.ex. Leonard et al., 2016). Utifrån den förståelsen kan exempelvis dans kallas för literacy, vilket enligt andra, inte minst i multimodalitetsfältet, är tveksamt. Jewitt (2006, s. 134ff) är kritisk till en sådan utvidgning av literacy-begreppet, då det leder till en fragmentering av begreppet så att det riskerar att bli meningslöst (jfr Street, 2000; jfr Kress, 2003, s. 23). Enligt henne är ett sådant synsätt, trots en vilja att vara radikal, tvärtom ett sätt att hysa det nya inom det gamlas domän. På så sätt isoleras varje "literacy" på samma sätt som läsande och skrivande traditionellt isolerats från meningsskapande och kommunikation. Enligt Jewitt ska alla modaliteters - och inte bara språkets - betydelse i meningsskapande beaktas, samtidigt som det är viktigt att undersöka de olika modaliteternas specifika möjligheter att bidra till meningsskapande.

Då artikeln undersöker meningsskapande som har permanens, det vill säga som entextualiseras, används ordet literacy i betydelsen skriftbruk, det vill säga användning av texter som är knutna till en materialitet (jfr Ledin, 2013, s. 6). Därmed inte sagt att andra modaliteter inte är meningsskapande, tvärtom. Artikeln tar inte ställning till i vilken grad literacy som forskningsbegrepp eller fält ska utvidgas.

Det är alltså utifrån det ökande skriftbruket i samhället kanske inte så förvånande att texter även tar plats $i$ ett av tradition kroppsligt ämne som idrott och hälsa, precis som skriftanvändning ökat $i$ alla yrken, inte minst i sådana som normalt inte betraktats som skriftyrken (Karlsson, 2006, s. 11). Inom forskningsfältet som lyfter fram betydelsen av ämnesspecifik literacy ("disciplinary literacy", t.ex. Moje, 2008) betonas vikten av det specifika språket för olika discipliner eller ämnesområden, då man menar att ämnesspråket är nära förknippat med kunskapsproduktionen inom de olika disciplinerna (Moje, 2008, s. 97; jfr Shanahan \& Shanahan, 2012).

I den här studien undersöks just kunskapsproduktionen i idrottsämnet, närmare bestämt vilken roll texter har i kunskapsbyggande i ett ämne med i huvudsak kroppsliga kunskaper. Mer specifikt är syftet alltså att undersöka hur kunskaper i idrottsämnet entextualiseras genom de skriftpraktiker som förekommer i ämnets undervisningspraktik. Det görs genom att identifiera skrifthändelser och textteman inom undervisningsblocket dans och rytmik i en högstadieklass. Undersökningen är en del av en etnografisk studie där högstadieklassens idrottsundervisning följdes under tre terminer. I artikeln redovisas resultaten som bygger på en analys av sex veckors undervisning om dans och rytmik och den därpå följande examinationen.

Studien fokuserar på aktiviteter kring elevernas läsande och skrivande i en process med att lära sig att dels komponera ett dansprogram, dels göra text av det, och på de texter som ingår i aktiviteterna. Ett delsyfte är därför att visa hur entextualiseringsprocessen under undervisningsblocket, det vill säga entextualisering och recentering i upprepade cykler, bidrar till det meningsskapande som sker i interaktioner där texter används (jfr Barton, 2007; Karlsson, 2006). Ett par mer konkreta frågor kan således formuleras:

- För vilka ändamål, kopplat till elevers och lärares handlingar, används skriftbaserade texter i ämnet idrott och hälsa? 
- Vad handlar de använda texterna om, det vill säga vilket speciellt ämnesinnehåll är det som entextualiseras?

\section{Den teoretiska referensramen}

Studien är teoretiskt förankrad i New Literacy Studies (NLS), en forskningsinriktning baserad på idén att läsande och skrivande bäst kan förstås som delar av situerade sociala praktiker. Från att ha haft betydelsen läs- och skrivkunnighet används literacy alltså nu även i överförd betydelse, exempelvis "physical literacy" som avser förmågor, attityder och kunskaper kopplade till fysisk aktivitet (Whitehead, 2007, s. 287; jfr Street, 2000). Karlsson (2006) använder termen skriftbruk när man menar konkret användning av skrift i olika sammanhang, det vill säga det som undersöks i denna studie.

I studien studeras alltså literacy som skriftbruk. Utifrån studiens NLS-perspektiv undersöks skriftpraktiker som är situerade i idrottsundervisningen i en högstadieklass där de får sin mening samtidigt som de är inbäddade i en vidare social och kulturell kontext och påverkas av exempelvis läroplanens skrivningar (jfr Barton \& Hamilton, 1998). Skriftpraktiker synliggörs i skrifthändelser, vilka är konkreta aktiviteter där skrift har en roll (Barton \& Hamilton, 2000, s. 7). I studien kan en skrifthändelse exempelvis utspela sig kring en skriftbaserad dansinstruktion som en grupp elever samtalar om. Att instruktionen ges skriftligt istället för muntligt påverkar idrottsundervisningen, men den skriftliga instruktionen påverkas också av idrottsämnet: texter både formar miljön och formas av miljön, och läraren och eleverna tillägnar sig den form av skriftbruk som tjänar syftet i denna speciella domän, det vill säga skolan eller mer preciserat idrottsundervisningen (jfr Barton, 2007).

För att undersöka denna specifika form av skriftbruk används begreppen skriftpraktik och skrifthändelse. Då skriftpraktiker synliggörs i skrifthändelser, används skrifthändelse som analysenhet. Texter har per definition en avgörande roll i skrifthändelser, och därför analyseras dessutom de specifika texterna och deras roll i aktiviteterna.

Entextualiseringsbegreppet har använts för att beskriva transformation av tal till skriven text (Androutsopoulos, 2014; Jacquemet, 2009; Poveda et al., 2005), transformation av social aktivitet till semiotiska representationer, som fotografier (Jones, 2009), och för att identifiera och analysera spår av språk och textuellt material som resurser för meningsskapande (Leppänen et al., 2013). Det har också använts i en bred betydelse som tal positionerat som "a verbal thing to which we can refer" (Massoud \& Kuipers, 2008, s. 217).

Hanell (2017), som studerat kommunikationen av kunskap om hälsa för nyblivna föräldrar $\mathrm{i}$ ett internetforum, beskriver entextualisering som en process där handlingar och händelser blir till en "diskursiv enhet" (s. 57), exempelvis en skriven text, och recentering som en process där handlingar med hjälp av denna text placeras in i ett nytt sammanhang. Som exempel ges påståendet "Jag gick upp $30 \mathrm{~kg}$ under min senaste graviditet", det vill säga något som bygger på en räcka handlingar som 
packas ihop till en erfarenhet vilken kan ges språklig form i en text, vilket i sin tur möjliggör en recentering i ett nytt sammanhang (s. 59). Entextualisering har likheter med begrepp som rekontextualisering (t.ex. Linell, 1998), reifiering ("reification", Wenger, 1998) och resemiotisering ("resemiotization", Iedema, 2003), vilka också betecknar transformella, det vill säga omvandlande, processer mellan yttranden, texter eller semiotiska modaliteteter (t.ex. skrift och bild, jfr Björkvall, 2009). Den exakta betydelsen varierar beroende på vilken transformell process som avser beskrivas (Hanell \& Salö, 2015, s. 4). Bauman och Briggs (1990, s. 67) påpekar att entextualiseringsprocessen inte ska ses som en cirkelrörelse från text till kontext till text. Snarare kan den ses som en cykel där varje ny entextualisering redan innehåller recenteringar. På så sätt "hårdnar" eller "stelnar" en entextualisering alltmer och lösgörs från den ursprungliga kontexten, när den snurrar runt flera varv i cykler av språk- och textanvändning (Scollon \& Scollon, 2004, s. 28). Genom att följa entextualiseringsprocesser över tid, som i denna studie, kan en del av denna transformation, i detta fall idrottsämnets "hårdnande", fångas.

Begreppet entextualisering har, som beskrivits ovan, använts på skilda sätt i forskning utifrån respektive studies kunskapsobjekt. I föreliggande studie undersöks alltså specifikt hur kunskaper i idrottsämnet entextualiseras och i vilket syfte. Mitt sätt att använda begreppet entextualisering liknar Hanells (2017) i det att det handlar om hur handlingar entextualiseras och att texterna används i kunskapsbyggande syfte. Men min studie handlar om texternas funktion i den studerade verksamheten, ett typiskt fokus i NLS-studier. Hanells kunskapsobjekt är villkoren för kommunikationen, vilket motiverar en diskursanalys.

\section{Literacy i idrottsämnet}

Av tradition har läs-, skriv- och språkutveckling varit språkämnenas, framför allt svenskämnets $^{2}$ (eller motsvarande i andra länder), ansvar. Forskare inom fältet för ämnesspecifik literacy eller "disciplinary literacy" menar dock att även lärare i andra ämnen bör arbeta integrerat med språk och ämnesinnehåll, och att sådant arbete är en fördel för elevers lärande (Moje, 2008; Schleppegrell, 2004; Shanahan \& Shanahan, 2008). Chandler-Olcott (2017) argumenterar med idrottsämnet som exempel för en utvidgning av synen på språk och literacy inom detta fält och betonar vikten av att anpassa literacy-undervisningen till idrottsämnets karaktär. Ett exempel på en ytterligare utvidgning av literacy är, som nämnts, att förstå och undersöka dans som literacy och därmed expandera barns och lärares literacyrepertoarer genom förkroppsligat kunnande (Leonard et al., 2016; jfr ovan). I den här artikeln undersöks istället literacy som skriftbruk i relation till den övergripande praktiken för att komma åt frågor kring förändrat förkroppsligat lärande i idrottsämnet.

\footnotetext{
${ }^{2}$ Svenska skolan har idag två svenskämnen: svenska och svenska som andraspråk och båda ämnena har ett huvudansvar för läs-, skriv- och språkutveckling för de elever som läser respektive ämne.
} 
Literacy i betydelsen skriftbruk i idrottsämnet har internationellt främst uppmärksammats i teoretiska resonemang snarare än genom empiriska undersökningar. Dessa artiklar kan grovt delas in i tre kategorier utifrån synen på vilken roll texter kan eller bör ha i idrottsundervisningen: idrott och hälsa som ett verktyg $i$ allmän läs- och skrivundervisning (t.ex. Ballinger \& Deeney, 2006), läsande och skrivande som ett sätt att lära sig ämnesinnehåll i idrottsämnet (t.ex. Ming, 2012) och ämnesspecifik literacy eller "disciplinary literacy" (t.ex. Chandler-Olcott, 2017, se ovan).

\section{Metod och material}

Den etnografiska studie om skrift- och bedömningspraktiker i idrottsämnet som denna artikel bygger på innebär att forskaren långvarigt engagerat sig i det sammanhang som ska studeras. Traditionellt förknippas etnografi med antropologiska studier och kan beskrivas utifrån graden av koppling till ursprunget, det vill säga antropologin. Den starkaste kopplingen handlar om att använda och analysera med etnografiska metoder ("doing ethnography"), den näst starkaste om att tillämpa ett etnografiskt perspektiv ("ethnographic perspective"), och den svagaste kopplingen handlar om att använda etnografiska verktyg ("using ethnographic tools") (Green \& Bloome, 1997, s. 183). Studiens teoretiska ramverk, NLS, bygger på etnografiska traditioner, och i studien används metoder hämtade från etnografin, så som deltagande observation med fältanteckningar, fotografering, informella samtal och intervjuer. Därmed är ett etnografiskt perspektiv det som bäst beskriver studiens ansats.

Traditionellt antropologiskt arbete har haft fokus på att göra det främmande bekant, i det att man försökt förstå annorlunda, ofta avlägsna levnadssätt och kulturer. Nyare etnografiska ansatser, så som lingvistisk etnografi (t.ex. Copland \& Creese, 2016), fokuserar istället på att göra det bekanta främmande, då man blottlägger vardagsrutiner och fångar in hur dessa uppenbarar sig i realtid (Heller, 2011). Inom etnografisk forskning anses forskarens egna kulturella och tolkande förmågor avgörande för att förstå de komplexa förvecklingar av situerade vardagsaktiviteter bland människor som studeras, vilket tar tid och engagemang. Min nästan trettioåriga erfarenhet av undervisning på högstadiet gör det lättare att förstå deltagarna, vilket ofta skrivs fram som en viktig aspekt av etnografisk forskning (t.ex. Copland \& Creese, 2016).

Den deltagande läraren är i yngre medelåldern och har arbetat i 15 år som idrottslärare. Klassen består av 25 elever: tretton flickor och tolv pojkar. Alla elever och föräldrar lämnade informerat samtycke till deltagande. Skolan ligger i en villaförort i Mellansverige. Jag deltog i sex av sju lektioner och genomförde tre semistrukturerade intervjuer (Bryman, 2011): två gruppintervjuer med fem flickor respektive sex pojkar, utifrån elevernas val av intervjutillfälle och intervjugrupp, och en intervju med läraren. Jag deltog också i två av fem redovisningstillfällen av elevernas uppvärmningsprogram. Dessutom samtalade jag med läraren $i$ anslutning till varje lektion och med eleverna under de ganska få tillfällen som det höga undervisningstempot tillät. Elevernas samtal med varandra spelades inte in, dels för att inte störa undervisningen mer än nödvändigt, dels på grund av den höga musiken. Materialet presenteras i tabell 1. 
Tabell 1. Material.

\begin{tabular}{lllll}
\hline Fältanteckningar & $\begin{array}{l}\text { Video- och } \\
\text { ljudupptagningar }\end{array}$ & Fotografier & Lärartexter & Elevtexter \\
\hline Från sex lektioner & Intervjuer 75 min., & 8 tavel-texter, 4 & 25 ifyllda bedömnings- & 6 musik- \\
och två redovisnings- & videofilm från & laminerade & mallar, 6 A4-papper, en & analyser, \\
tillfällen. & lektioner 76 min. & skyltar. & PowerPoint-presentation, & 25 skriftliga \\
10 renskrivna A4- & 22 A4-ark & & 3 skärmklipp, ett & uppvärmnings- \\
ark. & transkriberat. & & Excel-ark. & program. \\
\hline
\end{tabular}

Transkriptionen av videoupptagningarna har genomförts enligt transkriptionsnyckeln nedan (tabell 2). Då syftet med analysen av klassrumskommunikationen är av innehållslig karaktär, har en grov transkription tillämpats (jfr Norrby, 2014, s. 99).

Tabell 2. Transkriptionsnyckel.

\begin{tabular}{ll}
\hline /---/ & Utelämnad kommunikation. \\
\hline (xxx) & Ohörbar kommunikation. \\
(pekar på tavlan) & Kroppsliga handlingar som är del i kommunikationen. \\
/berättar om låt, artist och BPM/ & Handlingar i kommunikationen vilka redovisas översiktligt. \\
\hline
\end{tabular}

Analysens första steg är att i fältanteckningarna och transkriptionerna identifiera skrifthändelser. Därefter analyseras skrifthändelserna utifrån Hamiltons (2000) beskrivning av grundläggande synliga och icke-synliga element i skrifthändelser (tabell 3).

Tabell 3. Grundläggande element i skrifthändelser och skriftpraktiker. Översättning av Hamiltons tabell (2000, s. 17).

\begin{tabular}{ll}
\hline Element som är synliga i skrifthändelser & $\begin{array}{l}\text { Icke-synliga aspekter som bygger upp } \\
\text { skriftpraktiker }\end{array}$ \\
\hline $\begin{array}{l}\text { Deltagare: människor som kan ses interagerande } \\
\text { med de skrivna texterna. }\end{array}$ & $\begin{array}{l}\text { Dolda deltagare: Andra människor involverade i } \\
\text { skapandet, tolkandet, spridandet eller reglerandet av } \\
\text { texterna på andra sätt. }\end{array}$ \\
$\begin{array}{ll}\text { Inramning: de närmaste fysiska omständigheterna } \\
\text { för interaktionen. }\end{array}$ & $\begin{array}{l}\text { Den domän där händelsen äger rum och där den får } \\
\text { sin mening och sitt sociala syfte. }\end{array}$ \\
Redskap: de materiella redskapen (inklusive & $\begin{array}{l}\text { Alla andra resurser som tas in i skriftpraktiken } \\
\text { inklusive icke-materiella värden, förståelser, sätt att }\end{array}$ \\
texterna). & $\begin{array}{l}\text { tänka, känslor, förmågor och kunskaper. } \\
\text { Aktiviteter: handlingar som genomförs av }\end{array}$ \\
Strukturerade rutiner och vägar som underlättar eller \\
deltagarna i skrifthändelsen. & $\begin{array}{l}\text { reglerar handlingar; regler som anger vem som är } \\
\text { lämplig eller tillåten att handla; vem deltar/deltar inte, }\end{array}$ \\
& vem kan/kan inte delta i specifika aktiviteter. \\
\hline
\end{tabular}

De synliga elementen analyseras först. I studien är deltagarna alltid läraren och antingen eleverna eller grupper av elever. Inramningen kan handla om att eleverna 
sitter på stolar eller på golvet när de skriver eller att de är ombytta eller inte ombytta. De materiella redskapen är, förutom texterna vilka alltså undersöks specifikt (se nedan), exempelvis musikanläggningen. Aktiviteterna är kroppsliga och språkliga handlingar, som att träna steg utifrån en skriftlig instruktion, skriva på tavlan eller ställa en fråga om inlämningstexten.

Icke-synliga element i skrifthändelser består av dolda deltagare, den aktuella domänen, andra resurser än de materiella samt rutiner och regler. Dolda deltagare i studien är exempelvis styrdokumentsförfattare. Domänen, det vill säga idrottsundervisningen i skolan, ger skrifthändelsen, exempelvis en skriftlig övning av musikanalys, dess mening och sociala syfte. De osynliga redskapen är exempelvis kunskaper som deltagarna tar med sig in i händelsen. Kring aktiviteterna finns rutiner och regler för vad som är möjligt att göra. I skolan är det naturligt att läraren bestämmer lektionens innehåll, och det vanliga är att eleverna räcker upp handen om de vill säga något, exempelvis.

Utifrån dessa aspekter identifieras skriftpraktikerna som kan beskrivas som mönster skapade av återkommande skrifthändelser. Under den sexveckorsperiod som studien omfattar förekommer av förklarliga skäl få skrifthändelser inom vissa identifierade skriftpraktiker, exempelvis skriftpraktiken för presentation av undervisningsblock. Då jag fölit läraren och klassen under tre terminer, vet jag att det är en förekommande skriftpraktik. Detta gäller även andra identifierade skriftpraktiker som synliggörs i få skrifthändelser under de sex veckorna.

För att undersöka vilka ämneskunskaper som entextualiseras görs en enkel analys av textteman i de använda texterna. Texttema-analysen är inspirerad av Jämtelid (2002) och Hellspong och Ledin (1997). Jag undersöker vilka ämnesspecifika teman som förekommer i de använda texterna. Syftet är att undersöka vad texterna handlar om, och temat ses som en övergripande innehållslig kategori, snarare än en formell och grammatisk kategori som i den traditionella textlingvistiken (jfr Jämtelid, 2002, s. 67ff). En av utgångspunkterna är att texterna ska förstås i situationskontexten, det vill säga skrifthändelsen, och i den större verksamhet de är inslag i, det vill säga idrottsundervisningen i skolan (jfr Hellspong \& Ledin, 1997, s. 117-118). Därför söker jag identifiera de ämnesspecifika teman som förekommer i texterna, och frågan blir då:Vilket innehåll handlar texten om? Konkret innebär detta att analysen av varje text först identifierar vad varje grafisk mening handlar om genom en abstraktion som resulterar i innehållsliga teman, det vill säga teman som har med idrottsämnets undervisningsinnehåll att göra. Dessa teman kategoriseras, utifrån vad de handlar om i stort i den text och skrifthändelse där de återfinns, och genom en abstraktion, i övergripande teman vilka kallas temakategorier. Exempelvis placeras temana progression, leda gruppen, manusbundenhet och testa tekniken i den större temakategorin Performans, då alla dessa teman i den analyserade texten och i skrifthändelsen handlar om performans, det vill säga elevernas uppvisning av sitt uppvärmningsprogram. Ett tema kan få underkategorier på flera nivåer, exempelvis Rörelse: steg: mambo (jfr Jämtelid, 2002, s. 69). 


\section{Entextualiserat ämnesinnehåll}

Tabell 4 visar resultatet av texttema-analysen. Den vänstra kolumnen visar alla texter som förekommer i de elevcentrerade skriftpraktikerna (se nedan). Till höger visas texternas innehållsliga teman. Den större temakategorin markeras med fet stil. Teman på olika nivåer särskiljs med ett kolon och teman på samma nivå med ett komma. De temakategorier som identifierats är Musikanalys, Rörelse, Performans, Inramning av lektion eller aktivitet, Elevers önskemål, Bedömning av inlämningstext, Bedömning av performans, Betygsbedömning av performans, Betygsbedömning av inlämningstext och Bedömningskommentar.

Tabell 4. Texter och textteman i elevcentrerade skriftpraktiker.

\begin{tabular}{ll}
\hline Text & Textteman \\
\hline A4-papper som eleverna fyllt med vertikala streck i & Musikanalys: taktanalys, BPM. \\
fyrgrupper. (Lektion 1, L1) & \\
Taveltext: Facit av taktanalys. (L1) & Musikanalys: taktanalys. \\
Rörelseprogram till musik åk 8. Instruktion till & Musikanalys: val av låt, takt. \\
examinationsuppgiften. A4-papper och & Rörelse: rörelseriktningar, kvalitet, engagerade muskler. \\
PowerPoint-bild. (L1) & Performans: progression, leda gruppen, \\
& manusbundenhet, testa tekniken.
\end{tabular}

Vi är på gång. Exempel på musikanalys. A4-papper. (L1)

Musikanalys "save tonight". A4-papper med början av analys av låten Save tonight. (L2)

Elevernas fortsättning av analys av Eagle-Eye Cherry: Save tonight. A4-papper. (L2)

Taveltext: Facit på tavlan. (L2)

Taveltext: Vad behöver ni mer, vad är svårt?

Taveltext: Kvalitet och utmaning. (L2)

A4-papper med namn på nio steg. (L3)

Taveltext: Lektion idag. (L3)

Nummerdansen - musikanalysen "Alcazar" - stay the night. A5-papper. (L4)

Taveltext: Exempel på Nummerdansen. (L4)

Elevernas version av Nummerdansen. A5-papper.
Musikanalys: BPM, formled, taktanalys, låttext, fakta om låten.

Rörelse: steg.

Musikanalys: formled, taktanalys, låttext, fakta om låten.

Rörelse: steg.

Musikanalys: formled, taktanalys, BPM.

Musikanalys: formled, taktanalys, BPM.

Elevers önskemål: inspiration, snurr, timing.

Rörelse: bedömning av rörelse: svårighet, kvalitet, variation, koordination.

Rörelse: steg.

Inramning av lektion eller aktivitet: lektionsinnehåll: namn på tre låtar.

Inramning av lektion eller aktivitet: lektionens syfte: rörelse: rörelsebank, takt.

Musikanalys: formled, taktanalys, fakta om låten.

Rörelse: rörelseriktningar, rörelsemönster.

Inramning av lektion eller aktivitet: instruktion: rörelse.

Musikanalys: formled, taktanalys.

Rörelse: steg, rörelseriktningar, rörelsemönster.

Rörelse: steg, rörelseriktningar, rörelsemönster. 
Tabell 4. (Kontinuerlig)

Taveltext:Tänk på! (L4)

Fyra laminerade papper med namn på rörelser.

(L6)

Taveltext: Schematisk bild av koreografi. (L6)

Inlämningstext: Musikuppvärmning. 1-2 hand-

eller datorskrivna A4-papper. (Lämnas in i förväg, tas fram vid redovisningstillfället.)

Bedömningsmall för musikuppvärmning. A4-

papper.

(Fem redovisningstillfällen)
Rörelse: kvalitet, takt, våga.

Rörelse: rörelseriktningar.

Rörelse: koreografi.

Musikanalys: formled, taktanalys, fakta om låten.

Rörelse: steg.

Bedömning av performans: rörelse: svårighet, kvalitet, takt, rörelsemönster.

Bedömning av performans: följa planering, leda gruppen: adressera alla, tydliga övergångar.

Bedömning av inlämningstext: musikanalys, stegens koppling till musiken, rörelsernas karaktär.

Betygsbedömning av performans: A, C, E.

Betygsbedömning av inlämningstext: $\mathrm{A}, \mathrm{C}, \mathrm{E}$.

Bedömningskommentar: (+ och -$)$ till varje elev.

Tabell 4 följer undervisningens kronologi och visar att texttemat Musikanalys dominerar i början för att sedan ge plats år temat Rörelse, vilken är det oftast förekommande texttemat. Texttemat Performans förekommer i instruktionstexten och i bedömningsmallen. Texttemana elevers önskemål, lektionens syfte och instruktion handlar om rörelse. Det förstärker bilden av "rörelse" som det mest frekvent men också det mest nyanserat entextualiserade ämnesinnehållet, då det innehåller flera underteman och förekommer på flera nivåer i texttema-analysen.

\section{Skriftpraktiker}

Även om lektionerna mestadels innehåller kroppsliga övningar och muntliga instruktioner, används texter på varje lektion. Vissa skriftpraktiker är mest inriktade mot lärarens handlingar, medan andra skriftpraktiker tydligare kan kopplas till elevernas handlingar. De lärarcentrerade skriftpraktikerna handlar om planering och presentation av undervisningsblock, rutiner kring undervisningen och utvärdering och reflektion. Då elevcentrerade skriftpraktiker kan antas ha störst betydelse för kunskapsbyggandet inom ämnesblocket, redovisas de mer utförligt nedan med exempel på skrifthändelser.

\section{Elevcentrerade skriftpraktiker}

De identifierade elevcentrerade skriftpraktikerna är följande: skriftpraktik för 1) övning av musikanalys, 2) träning av kroppslig färdighet kopplad till dans och 3) bedömning och kunskapsredovisning. I tabell 5 visas de identifierade elevcentrerade skriftpraktikerna och övergripande resultat av analysen av skrifthändelser (jfr tabell 3). ${ }^{3} \mathrm{I}$ kolumnen Redskap anges förekommande materiella redskap i varje skriftpraktik. De

${ }^{3}$ För att inte göra tabell 5 alltför svårläst visas inte hela analysen. 


\section{A.-M. Norberg}

angivna aktiviteterna, det vill säga handlingarna, är sådana som framstår som särskilt relevanta för skriftpraktiken, då det förstås är omöjligt att ta med alla handlingar i en tabell. Exempel på lärarhandlingar och motsvarande elevhandlingar som inte tas med är: ställer och besvarar frågor, instruerar muntligt och kroppsligt, skriver på tavlan samt sköter musiken. ${ }^{4}$ Däremot kan en precisering av sådana handlingar tas med, exempelvis "skriver facit på tavlan".

Tabell 5. Elevcentrerade skriftpraktiker samt redskap och aktiviteter i skrifthändelser.

\begin{tabular}{|c|c|c|c|}
\hline Identifierad & \multicolumn{3}{|c|}{ Element i samtliga skrifthändelser i elevcentrerade skriftpraktiker } \\
\hline $\begin{array}{l}\text { Skriftpraktikens } \\
\text { huvudfunktion } \\
\text { Övning av } \\
\text { musikanalys }\end{array}$ & $\begin{array}{l}\text { Tomt A4-papper, penna, } \\
\text { klocka, musikanläggning. } \\
\text { Texter: Musikanalys, Vi är } \\
\text { på gång, Save tonight (två } \\
\text { versioner), taveltext. }\end{array}$ & $\begin{array}{l}\text { Aktiviteter: handlingar, } \\
\text { elever } \\
\text { Skriver namn på formled. } \\
\text { Markerar takt som streck på } \\
\text { papper. } \\
\text { Räknar ut BPM. } \\
\text { Gör övningar på } \\
\text { musikanalys. }\end{array}$ & $\begin{array}{l}\text { Aktiviteter: handlingar, } \\
\text { läraren } \\
\text { Skriver facit på tavlan. } \\
\text { Går igenom facit. } \\
\text { Markerar takt genom att } \\
\text { knäppa med fingrarna. }\end{array}$ \\
\hline $\begin{array}{l}\text { Träning av kroppslig } \\
\text { färdighet kopplad till } \\
\text { dans }\end{array}$ & $\begin{array}{l}\text { Papper med namn på nio } \\
\text { steg. } \\
\text { Taveltext. } \\
\text { Skyltar med namn på } \\
\text { rörelsemönster. } \\
\text { Musikanläggning. }\end{array}$ & $\begin{array}{l}\text { Tränar steg. } \\
\text { Skapar dans i grupper. } \\
\text { Förhandlar med varandra. } \\
\text { Övar takt. }\end{array}$ & $\begin{array}{l}\text { Skriver namn på steg på } \\
\text { tavlan. } \\
\text { Beskriver och visar steg, } \\
\text { rörelsemönster, takt och } \\
\text { rörelsekvalitet. } \\
\text { Läser högt ur använda } \\
\text { texter. } \\
\text { Ritar dansmönster på } \\
\text { tavlan. }\end{array}$ \\
\hline $\begin{array}{l}\text { Bedömning och } \\
\text { kunskapsredovisning }\end{array}$ & $\begin{array}{l}\text { Taveltext, iPad, } \\
\text { instruktionstext, } \\
\text { PowerPoint-bild } \\
\text { med instruktionstext, } \\
\text { bedömningsmall, skriftlig } \\
\text { inlämning. } \\
\text { Musikanläggning. }\end{array}$ & $\begin{array}{l}\text { Uttrycker önskemål om } \\
\text { undervisningsinnehåll. } \\
\text { Ser film på sin dans. } \\
\text { SerYouTube-klipp. } \\
\text { Söker passande låt. Söker } \\
\text { nya steg. } \\
\text { Väljer textformat. } \\
\text { Skriver text. } \\
\text { Lämnar in text. Berättar } \\
\text { om sitt } \\
\text { program. } \\
\text { Läser tyst och högt } \\
\text { ur sin text. } \\
\text { Genomför dansprogram. } \\
\text { Använder sin text som } \\
\text { manus. }\end{array}$ & $\begin{array}{l}\text { Går igenom instruktion } \\
\text { till inlämningsuppgift. } \\
\text { Beskriver och visar } \\
\text { rörelsekvalitet. Undervisar } \\
\text { utifrån elevönskemål. } \\
\text { Filmar dans. } \\
\text { Visar film och pekar på } \\
\text { utvecklingsaspekter. } \\
\text { Skriver bedömnings- } \\
\text { aspekter på tavlan och } \\
\text { förklarar och visar dem. } \\
\text { Samlar in och } \\
\text { läser elevtexter. Skriver } \\
\text { bedömning. Meddelar och } \\
\text { förklarar bedömning. } \\
\text { Läser högt ur elev- } \\
\text { texter. } \\
\text { Gör elevers steg. }\end{array}$ \\
\hline
\end{tabular}

${ }^{4}$ Musikens roll undersöks inte men kan antas ha stor betydelse för meningsskapandet. 
Tabell 5 visar att såväl elev- som lärarhandlingar ofta kan relateras till de använda texterna och att texterna därmed används som funktionella redskap i skrifthändelserna. I entextualiseringsprocessen omvandlas handlingarna till texter som kan förflyttas till en ny kontext och där användas som kunskap i nya handlingar som kan omvandlas till nya texter och så vidare (jfr Hanell, 2017, s. 57). Hur detta praktiskt går till visas nedan.

\section{Skriftpraktik för övning av musikanalys}

Skriftpraktiken för övning av musikanalys är en typisk skolpraktik, där ett ämnesinnehåll tas upp i undervisningen med hjälp av muntliga genomgångar vid tavlan och därpå följande övningar. Eleverna sitter på stolar i det så kallade motionsrummet istället för på golvet $i$ idrottshallen. De är inte heller ombytta till idrottskläder. Även om denna skriftpraktik är en typisk skolpraktik, är den innehållsligt specifik för den studerade idrottsundervisningen.

Att räkna ut BPM (Beats per minute), att välja ut en låt med rätt BPM och att analysera låten framstår som nödvändiga handlingar för att förbereda en musikuppvärmning. Här visas skrifthändelser som exempel på hur eleverna får lära sig att räkna ut BPM och att analysera en låt och hur dessa handlingar entextualiseras till något som kan recenteras, det vill säga flyttas till en ny kontext, och därmed användas som kunskap i den fortsatta undervisningen (jfr Hanell, 2017).

\section{Exempel 1:Hur räknar man ut BPM? (L: läraren, E: elev)}

L: nu ska jag berätta vad det här pappret ska användas till ni har förberett BPM på musiken ni vet hur man räknar ut det

E: $\quad(\mathrm{xxx})$

L: ja såhär ska ni göra slå med fingret $\mathrm{i}$ bordet eller på handen eller nåt nu när ni inte har nåt bord så att ni hittar takten sen ska ni räkna antal slag under 15 sekunder gör det några gånger så att ni till slut kommer fram till samma siffra vad ska det multipliceras med för att få fram takten för en minut

E: fyra

L: precis

Läraren tycks veta att BPM tagits upp på musiken och frågar eleverna om de vet hur man räknar ut det. Han bekräftar det ohörbara elevsvaret och förklarar att eleverna ska slå med fingret och räkna antal slag så många gånger att de kommer till samma resultat, vilket sedan ska multipliceras med fyra. Läraren sätter på musiken och eleverna markerar takten på olika sätt, exempelvis genom att nicka med huvudet eller slå med ett finger på handen. Ganska snabbt börjar de rita streck på pappret, det vill säga entextualisera takten i form av streck i fyrgrupper, för att därefter räkna ut BPM.

Nästa lektion rekapituleras den föregående lektionen och läraren ger instruktioner till dagens övning: 


\section{Exempel 2: Titta på klockan!}

L: det första ni ska få göra är att ta ut BPM beats per minute på det här hur räknar man ut det

E: $\quad(\mathrm{xxx})$

L: ja och här kan ni titta på klockan /Läraren visar 15 sekunder på en stor klocka/ och sen gångrar man med (visar fyra fingrar) då får ni knacka lite på golvet, eller knäppa med fingrarna (knäpper med fingrarna) eller nicka med huvudet (nickar med huvudet) för att hitta pulsen. /Läraren sätter på musiken/ titta på klockan /Pekar på klockan, går till tavlan, börjar skriva./

Läraren frågar hur man räknar ut BPM och bekräftar det ohörbara elevsvaret. Därefter visar han 15 sekunder på klockan och antalet fyra (som 15 ska multipliceras med) med fyra fingrar. Han uppmanar eleverna att knäppa med fingrarna eller nicka med huvudet samtidigt som han själv gör dessa rörelser. Eleverna ska alltså visualisera 15 sekunder samtidigt som de förkroppsligar takten med knackningar eller nickningar.

I nästa exempel har läraren skrivit början av en musikanalys på tavlan med namn på fyra formled och en taktanalys i form av streck i fyrgrupper. Eleverna har fått samma text som även innehåller kortfattade beskrivningar av låtens musik och text och exempel på steg (se figur 1).

\section{Exempe1 3: Analys av låt}

L: nu har ni intro vers och refräng på tavlan och nu ska ni få göra en analys av en låt om man gör fel nu och skriver brygga istället för mellanspel så gör det inte så mycket det första gör vi gemensamt och sen vill jag att ni gör streck och när gör ni ett streck

$\mathrm{E}$ : när det gått en takt

L: och en takt räknar ni

E: fyra

E2: ska vi lämna in det

L: $\quad$ nej

/Läraren sätter på musiken. Han pekar på början av analysen på tavlan, räknar till fyra. Eleverna börjar skriva./

Läraren säger att eleverna ska få analysera en låt och att det inte gör något om man gör fel. Han uppmanar eleverna att göra streck och frågar när ett streck ska göras. Elevsvaret "När det gått en takt" leder till en ny fråga om hur man räknar ut en takt. När läraren satt på musiken, pekar han på tavlan och räknar till fyra, det vill säga räknar in takten. Eleverna börjar skriva streck och namn på formled i sina papper (se figur 1).

I figur 1 visas en entextualisering som är ett resultat av de olika handlingar som föregått övningen. Högst upp på pappret har eleven skrivit "15 sekunder X 4", en entexualisering där eleven recenterar den tidigare lektionens handlingar, exempelvis när läraren visade 15 sekunder med klockan och både sade och visade med fyra fingrar att det skulle multipliceras med fyra. Även strecken i fyrgrupper kan ses som 


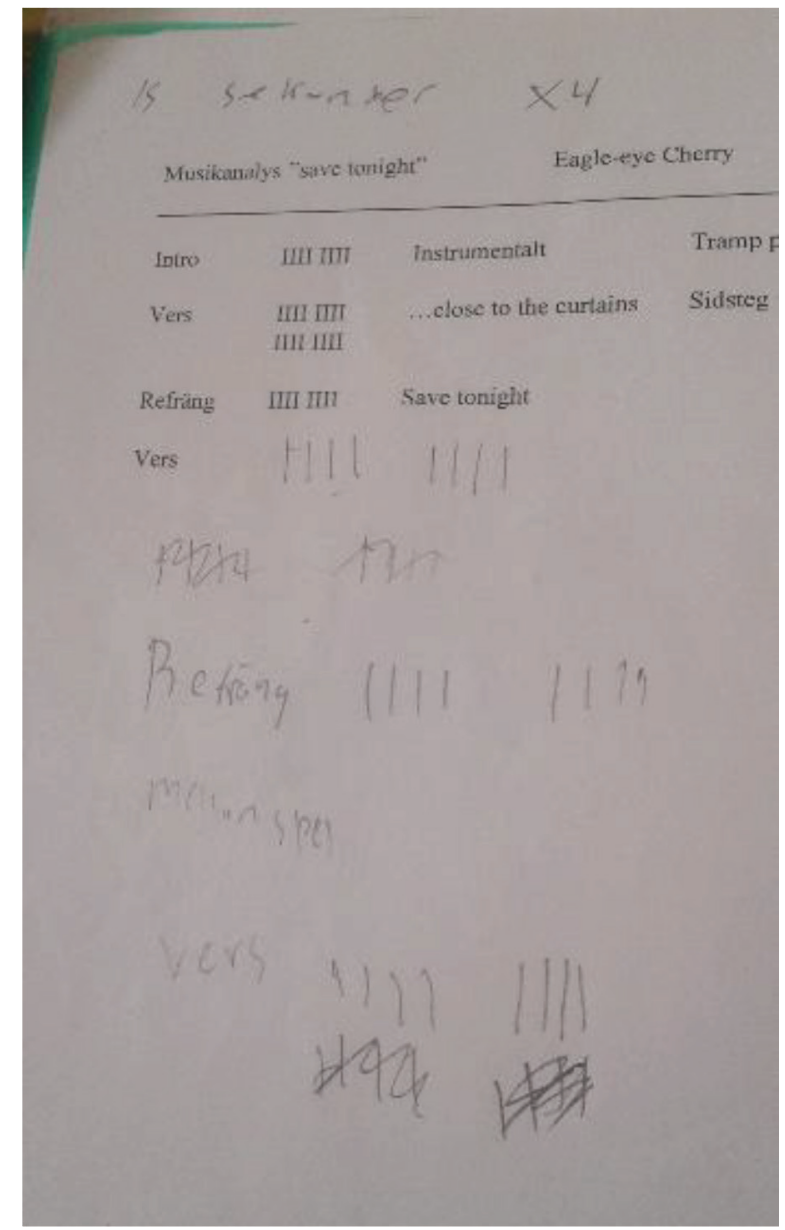

Figur 1. Elevlösning Musikanalys "save tonight".

en entextualisering av tidigare handlingar, som att nicka med huvudet för att hitta takten. Formledet "mellanspel" har inte tagits upp i undervisningen utan är en entextualisering (eller recentering) av ännu tidigare handlingar, kanske under musikundervisningen. Varje entextualisering innehåller recenteringar av tidigare handlingar och texter, och det går inte att säga vilken som är "den första entextualiseringen". Här visas hur ämnesinnehållet omformas genom en entextualiseringsprocess, där texter kan tas ur en kontext och flyttas till en ny, och där texten och kunskapen därmed framstår allt tydligare (jfr Scollon \& Scollon, 2004). Att läraren i händelsen ovan säger att det inte gör något om man gör fel nu, betyder att en tydlig, hårdnad entextualisering inte är något krav ännu.

\section{Skriftpraktik för träning av kroppslig färdighet kopplad till dans}

Delar av skriftpraktiken för träning av kroppslig färdighet kopplad till dans liknar samma instruktionspraktik vid tavlan som ovan, men delar av den representerar 
kanske något relativt nytt $\mathrm{i}$ idrottsämnet, nämligen att texter används $\mathrm{i}$ närhet till kroppsliga övningar och inte bara i samband med instruktioner, vilket skulle kunna hota de kroppsliga läroprocesserna. Skriftpraktiker förändras över tid (Säljö, 2000), och i forskning finns exempel på hur exempelvis videospel används i idrottsämnespraktiker (t.ex. Nyberg \& Meckbach, 2015). I den föreliggande studien förekommer framför allt korta texter på papper, förutom taveltext.

När steg tränas, är eleverna ombytta och skrifthändelserna äger rum $\mathrm{i}$ idrottshallen, både vid tavlan och i nära anslutning till de fysiska övningarna. Här ges exempel på två skrifthändelser där syftet är att lära sig kunskaper kopplade till rörelsemönster och steg.

\section{Exempel 4: Övning med nio steg}

L: här får ni ett papper med nio steg (delar ut ett papper till varje grupp, sätter sig på huk, läser innantill) det står gå på stället V-steg X-steg side step grapevine snurr hältouch armbåge mot knä och jumping jacks ni kan alla dem och nu vill jag att ni ställer er i en ring i grupperna och lägger pappret i mitten jag sätter på musiken ni får börja göra stegen tillsammans /Grupperna går till olika ställen i idrottshallen, lägger pappret i mitten och börjar dansa./

Läraren delar ut pappret och läser upp namnen på stegen. Han säger att eleverna kan dessa steg, vilket betyder att läraren visat dem och att eleverna tränat på dem. Dessa tidigare handlingar är en förutsättning för att entextualiseringen av de nio stegen kan användas i en övning på detta sätt. Läraren uppmanar varje grupp att ställa sig i en ring och lägga pappret i mitten. På lärarens uppmaning börjar eleverna göra stegen när han sätter på musiken.

I samband med en övning kallad 4-hörn delas klassen in i fyra grupper som ska komponera var sin dans. I varje hörn av idrottshallen lägger läraren en laminerad bild med dansande "streckgubbar", noter och en benämning med stor text på ett rörelsemönster: Rotation, Sidled, Framåt och bakåt och Högt och lågt. Innan eleverna börjar dansa ger läraren instruktioner:

\section{Exempel 5: 4-hörnsövning med olika rörelsemönster}

L: /---/ då jobbar man i grupper tillsammans alla gör samma steg och jag skulle önska att ni jobbar i två stycken åttor (skriver på tavlan: 2 st 8:or) två styck åttor vilket innebär det här (vänder sig till klassen) en två tre fyr fem sex sju ått (gör steg åt sidan) en två tre fyr fem sex sju ått (gör steg åt sidan) då har ni gjort två stycken åttor sen byter ni steg en två tre fyr fem sex sju ått (gör steg framåt, åt sidan, tittar på skyltarna, sätter sig på huk) jag skulle vilja att ni inte kör de här och sejfar idag att ni kör de här bara sidestep grapevine ( $x x x)$ ni kommer att få nya övningar

Läraren beskriver i tal, genom att skriva på tavlan och genom att kroppsligt visa olika rörelsemönster att och hur eleverna ska arbeta i två åttor. Han uppmanar eleverna att inte bara välja enkla steg. Grupperna samlas vid de fyra skyltarna och börjar dansa efter ett kort förhandlande om vilka steg de ska välja. Läraren filmar grupperna med 
en iPad för att senare visa det filmade för grupperna och föreslå utvecklingsområden. Efter cirka åtta minuter stoppas musiken och grupperna flyttar till nästa hörn med nya rörelser som kan läggas till dansen. Vid det andra stoppet samlar läraren eleverna för att ge tips i form av uppmaningar att agera på ett visst sätt: någon i gruppen ska räkna högt, de ska klappa och de ska markera stegen.

Entextualiseringarna av de nio stegen och de fyra rörelsemönstren kompletterar lärarens instruktioner och har en potential att hjälpa eleverna att fokusera på uppgiften (jfr Nyberg \& Meckbach, 2015). Istället kan läraren iaktta grupperna för att senare samla klassen och visa hur rörelserna kan utvecklas. Att eleverna får se namnen på stegen kan också bidra till att de lär sig namnen och minns dem bättre när de ska komponera sin egen koreografi och presentera den som text.

Pappret med de nio stegen och skyltarna med de fyra rörelsemönstren kan ses som exempel på progressionen i entextualiseringsprocessen, där delar av tidigare handlingar recenteras i ett nytt sammanhang och entextualiseringen därmed hårdnar alltmer, då den lösgörs från den ursprungliga kontexten (jfr Scollon \& Scollon, 2004; Hanell, 2017, s. 57). För att kunna använda pappret med de nio stegen måste eleverna dels känna till benämningarna på stegen, dels kunna utföra stegen. Skyltarna med rörelsemönstren kräver ytterligare kunskaper: eleverna måste kunna placera stegen de kan inom rörelsemönstren, och det kan ses som en fördel att kunna benämna stegen - och inte bara visa dem - då de i grupper ska förhandla om sin dans.

\section{Skriftpraktik för bedömning och kunskapsredovisning}

Skriftliga bedömningspraktiker har lång tradition i skolan, och även i idrottsämnet har det på senare tid blivit vanligare med skriftliga kunskapsbedömningar (Tolgfors, 2017). I studien förekommer skriftliga bedömningspraktiker för olika syften. ${ }^{5}$ Inlämningstexten används som underlag för en summativ bedömning men också av vissa elever som stöd i samband med uppvisningen av uppvärmningsprogrammen som i följande exempel:

\section{Exempel 6: Lägg pappret framför dig!}

L: varsågod Jonas berätta för oss /Jonas tittar på sin text och berättar om låt, artist och BPM./

L: (läser från texten) introt stå stilla ta långsamt upp händerna på nacken i några sekunder tar du axlarna åt höger och vänster som uppbyggnad till droppet /Jonas visar./

L: Redo

E: ja (lägger ifrån sig texten)/Läraren sätter på musiken och Jonas börjar dansa, tappar bort sig, tar upp texten./

L: (stänger av musiken) vad var det du skulle ha gjort

E: (tittar på texten och läser upp) steg fram /---/ och så V-steg med händerna upp i luften

${ }^{5}$ De skriftliga bedömningspraktikerna analyseras i en Författaren (kommande). 
L: lägg pappret framför dig så kör vi igen (sätter på musiken från början)

E: /tittar på texten och dansar, tappar bort sig, tittar på läraren/

L: /gör alla Jonas steg/

/Jonas kan följa hans rörelser och genomföra sitt program./

Jonas tittar på sin text och berättar fakta om låten. Läraren läser upp några av hans steg, och Jonas visar stegen. När Jonas börjat dansa, tappar han bort sig ganska snabbt och tar upp texten. Läraren frågar vad Jonas skulle ha gjort enligt texten. Jonas tittar på sin text och läser upp stegen som han missat. Läraren uppmanar nu Jonas att lägga texten framför sig, så att han kan använda den som stöd. Trots det tappar han bort sig igen, när han börjar dansa. Han tittar på läraren som då gör alla Jonas steg enligt texten, vilket gör att Jonas kan titta på honom och genomföra sitt program.

Den entextualiserade dansen används som stöd av både eleven och läraren, förutom att den alltså används som ett bedömningsunderlag. Lärarens recentering av elevens text, såväl genom språkliga som kroppsliga handlingar, fungerar som en påminnelse. Vissa elever använder texten som ett manus, men det tycks inte fungera för Jonas: kanske utgör texten snarare ett hinder för honom. Han behöver lärarens rörelser som stöd, vilket han kan få i och med att läraren har Jonas text framför sig.

\section{Sammanfattande diskussion}

Syftet med artikeln har varit att undersöka hur kunskaper i idrottsämnet entextualiseras genom de skriftpraktiker som förekommer i ämnets undervisningspraktik. Det har gjorts genom att identifiera textteman och skrifthändelser inom undervisningsblocket dans och rytmik i en högstadieklass. Syftet har också varit att visa hur entextualiseringsprocessen under undervisningsblocket bidrar till det meningsskapande som sker i interaktioner där texter används. Detta betyder att alla de interaktioner där texter inte används utesluts i studien och att de praktiker som inte entextualiseras blir osynliga. Därför är det på sin plats att poängtera att det mesta inte entextualiseras och att rörelse och kroppslig kunskap är det som stort dominerar lektionerna. Viktigt att poängtera är också att studien inte syftar till att värdera om texter är bra eller dåligt för lärandet i dans. Nedan diskuteras studiens resultat.

Studien har visat att texter har en betydande roll i kunskapsbyggandet under dans och rytmik-blocket, bland annat som redskap för lärande, redovisning och bedömning av ämneskunskaper. Texttemaanalysen visar att teman kopplade till rörelse är de mest frekvent förekommande i de texter eleverna främst använder. Ämneskunskaper entextualiseras och recenteras i upprepade cykler genom hela undervisningsblocket. I och med att denna process sker med hjälp av olika handlingar, såväl språkliga som kroppsliga, och med hjälp av redskap som musik och texter, hårdnar entextualiseringen av de önskade kunskaperna alltmer och blir tydligare och tydligare. Som hårdast eller tydligast är entextualiseringen i elevernas inlämningstexter, det vill säga de entextualiserade danserna. Därmed kan dessa texter bland annat användas som stöd i samband med uppvisningarna. Då läraren har Jonas text, kan han visa stegen och 
Jonas kan genomföra sitt program. Å andra sidan kan den skriftliga texten ha varit ett hinder för Jonas - kanske har den kognitiva process som skrivandet inneburit stört hans kroppsliga lärande. För andra elever kan det dock vara tvärtom: att entextualiseringen av dansen, det vill säga en annan modalitet, underlättar lärandet (jfr Cope \& Kalantzis, 2009, s. 180ff). Emellertid är det tydligt att den entextualiserade dansen inte räcker för att visa kunnande i dans: därtill behövs framför allt performansen. Detta motiverar frågan om vad text - eller literacy - egentligen är eller kan vara $\mathrm{i}$ idrottsämnet.

Inom forskning om ämnesspecifik literacy betonas ämnesspråkets roll i kunskapsbyggandet (Moje, 2008; jfr Shanahan \& Shanahan, 2012), men i en literacystudie om idrottsämnet påpekas att det inte räcker med verbalspråket, då multimodala texter på ett bättre sätt kan fånga ämnet (Chandler-Olcott, 2017). En mer ämnesdidaktisk slutsats är alltså att literacy-aktiviteterna ofta kan anpassas mer till ämnets karaktär, och inte tvärtom, för att textanvändning ska ha en potential att utveckla den ämnesspecifika undervisningen.

I studien används literacy som i mångt och mycket anpassats till idrottsämnet. Ämnesbegrepp används på ett funktionellt sätt i tal och skrift såväl av läraren som av eleverna. Inlämningsuppgiften med musikanalys och planering av steg och rörelser är anpassad till ämnets karaktär eller "habits of practice" (Wickens et al., 2015, s. 76; jfr Quennerstedt, 2013) och är därmed kanske ett exempel på idrottsämnets anpassning till det moderna skriftsamhället (jfr Karlsson, 2006) - eller till gällande läroplan.

Att texter används i nära anslutning till fysiska övningar kan ses som ett ytterligare exempel på ämnesspecifik literacy. Det är fullt möjligt att dessa övningar underlättar en fördjupning av dansundervisningen (jfr Nyberg \& Meckbach, 2015), något som utpekats som ett utvecklingsområde (Larsson \& Karlefors, 2015). Å andra sidan kan textanvändning ses som något som stör det kroppsliga lärandet. Enligt Karlsson (2006) är användning av skrift för självständigt arbete ett drag i en ny skriftkompetens som krävs i nästan alla yrken. Därför är det viktigt, menar hon, att reflektera över skolans skriftkultur och vad den bör bestå av. En slutsats hon drar är att läs- och skrivarbetet hör hemma även $i$ ämnen som idrott och hälsa (s. 148). Frågan är hur mycket och inte minst vilken textanvändning som är motiverad i idrottsämnet utan att fokus tas från kroppsliga lärprocesser.

Läraren skriver ofta på tavlan, ibland flera gånger under en lektion. Taveltexter är starkt kopplade till situerade handlingar och suddas oftast ut i slutet av lektionen, vilket dock inte minskar deras betydelse för deltagarna (jfr Svensson, 2013). Att inte bara säga något utan också skriva eller rita det på tavlan avser troligen ha en förstärkande och fokuserande verkan (jfr Svensson, 2014). Chandler-Olcott (2017) föreslår att även elever ges små tavlor att skriva på istället för papper och penna i syfte att anpassa skrivandet till ämnets karaktär. I föreliggande studie skriver eleverna vid få tillfällen, men tavlor hade exempelvis kunnat användas i samband med planering av dans i grupper. Möjligen hade en tavla också varit praktisk i samband med övning av musikanalys, då eleverna skrev på A4-ark som sedan kastades. Ett annat alternativ 
hade varit att använda digitala skrivplattor och därmed även kunna skicka eller spara texter, framför allt med tanke på att inlämningsuppgiften skrevs både i skolan och hemma (jfr Åkerfeldt, 2014).

Studien fyller en empirisk lucka i forskningen om skriftbruk i idrott och hälsa. Det behövs fortsatt forskning om texters potentiella roll i skolämnen som traditionellt inte varit textmedierade. Inte minst handlar detta om kritisk forskning om vilka texter eller vilken literacy som är mest relevanta därvidlag, och vilken relation som föreligger mellan texten och performansen, som i den här studien, eller mellan texten och det praktiska kunnandet. Det är också relevant att utforska hur entextualiseringsprocessen rekonstruerar själva disciplinen.

\section{Referenser}

Androutsopoulos, J. (2014). Moments of sharing: Entextualization and linguistic repertoires in social networking. Fournal of Pragmatics, 73, 4-18. https://doi-org.db.ub.oru.se/10.1016/j.pragma.2014.07.013

Ballinger, D. A., \& Deeney, T. A. (2006). Physical Educators as Teachers of Literacy. Fournal of Physical Education, Recreation E Dance, 77(5), 18-23, DOI:10.1080/07303084.2006.10597873

Barton, D. (2007). Literacy: an introduction to the ecology of written language. 2. ed. Malden, MA: Blackwell.

Barton, D., \& Hamilton, M. (1998, 2012). Local literacies: Reading and writing in one community. London: Routledge.

Barton, D., \& Hamilton, M. (2000). Literacy practices. In D. Barton, M. Hamilton, \& R. Ivanič (Ed.), Situated literacies. Reading and writing in context (s. 7-15). London and New York: Routledge.

Bauman, R., \& Briggs, C. L. (1990). Poetics and Performance as Critical Perspectives on Language and Social Life. Annual Review of Anthropology, 19, 59-88.

Björkvall, A. (2009). Den visuella texten: Multimodal analys $i$ praktiken. Stockholm: Hallgren \& Fallgren.

Bryman, A. (2011). Samhällsvetenskapliga metoder. Malmö: Liber.

Chandler-Olcott, K. (2017). Disciplinary literacy and multimodal text design in physical education. Literacy, 51, 147-153. https://doi-org.db.ub.oru.se/10.1111/lit.12125

Cope, B., \& Kalantzis, M. (2009). “Multiliteracies”: New Literacies, New Learning. Pedagogies: An International fournal, 4(3), 164-195, DOI: 10.1080/15544800903076044

Copland, F., \& Creese, A. (2016). Ethical Issues in Linguistic Ethnography: Balancing the Micro and the Macro. In P. I. De Costa (Ed.), Ethics in Applied Linguistics Research. Language Research Narratives (s. 161-178). New York: Routledge.

Green, J., \& Bloome, D. (1997). Ethnography and ethnographers of and in education: A situated perspective. In J. Flood, S. Brice Heath \& D. Lapp (Ed.), Handbook of research on teaching and literacy through the communicative and visual arts (s. 181-202). Mahwah, NJ \& London: Lawrence Erlbaum.

Hamilton, M. (2000). Expanding the new literacy studies. Using photographs to explore literacy as social practice. In D. Barton, M. Hamilton, \& R. Ivanič (Ed.), Situated literacies: Theorising reading and writing in context (s. 16-34). London: Routledge.

Hanell, L. (2017). The Knowledgeable Parent. Ideologies of Communication in Swedish Health Discourse. Doctoral dissertation. Department of Swedish Language and multilingualism. Stockholm University.

Hanell, L., \& Salö, L. (2015). 'That's weird, my ob-gyn said the exact opposite!': Discourse and knowledge in an online discussion forum thread for expecting parents. Tilburg Papers in Culture Studies. Paper 125, Tilbury University.

Heller, M. (2011). Critical ethnographic sociolinguistics. In M. Heller (Ed.). Paths to post-nationalism: a critical ethnography of language and identity (s. 31-51). New York: Oxford University Press.

Hellspong, L., \& Ledin, P. (1997). Vägar genom texten: Handbok i brukstextanalys. Lund: Studentlitteratur.

Iedema, R. (2003). Multimodality, resemiotization: extending the analysis of discourse as multi-semiotic practice. Visual communication, 2(1), 29-57. https://doi.org/10.1177/1470357203002001751

Jacquemet, M. (2009). Transcribing Refugees: The Entextualization of Asylum Seekers' Hearings in a Transidiomatic Environment. Text \& Talk, 29(5), 525-546. https://doi.org/10.1515/TEXT.2009.028

Jewitt, C. (2006). Technology, literacy and learning: a multimodal approach. London: Routledge.

Jones, R. H. (2009). Dancing, skating and sex: Action and text in the digital age. Fournal of Applied Linguistics 6(3), 283-302. doi: 10.1558/japl.v6i3.283 


\section{Entextualiseringar av dans och rytmik $i$ idrottsundervisningen $i$ en högstadieklass}

Jämtelid, K. (2002). Texter och skrivande $i$ en internationaliserad affärsvärld [Elektronisk resurs]: flerspråkig textproduktion vid ett svenskt storföretag. Diss. Stockholm: Stockholms universitet, 2002. Stockholm.

Karlsson, A.-M. (2006). En arbetsdag $i$ skriftsamhället. Ett etnografiskt perspektiv på skriftanvändning $i$ vanliga yrken. Stockholm: Språkrådet.

Kress, G. (2003). Literacy in the New Media Age. New York \& London: Routledge.

Larsson, H., \& Karlefors, I. (2015). Physical education cultures in Sweden: fitness, sports, dancing ... learning? Sport, Education and Society, 20(5), 573-587, DOI: 10.1080/13573322.2014.979143

Ledin, P. (2013). Den kulturella texten: format och genre. Viden om Lcesning, 13, 6-18.

Leonard, A. E., Hall, A. H., \& Herro, D. (2016). Dancing Literacy: Expanding Children's and Teachers' Literacy Repertoires through Embodied Knowing. Fournal of Early Childhood Literacy, 16(3), 338-360.

Leppänen, S., Kytölä, S., Jousmäki, H., Peuronen, S., \& Westinen, E. (2013). Entextualization and resemiotization as resources for identification in social media. In P. Seargeant, \& C. Tagg (Ed.), The language of social media: communication and community on the internet (s. 112-138). Basingstoke: Palgrave.

Linell, P. (1998). Discourse across boundaries: On recontextualizations and the blending of voices in professional discourse. Text,18(2), 143-157.

Massoud, L. A., \& Kuipers, J. C. (2008). Objectification and the inscription of knowledge in science classrooms. Linguistics and Education, 19, 211-224. https://doi-org.db.ub.oru.se/10.1016/j.linged.2008.05.009

Ming, K. (2012). 10 Content-Area Literacy Strategies for Art, Mathematics, Music, and Physical Education. Clearing House: A fournal of Educational Strategies, Issues and Ideas, 85(6), $213-220$. $10.1080 / 00098655.2012 .691568$

Moje, E. B. (2008). 'Foregrounding the disciplines in secondary literacy teaching and learning: A call for change.' Fournal of Adolescent and Adult Literacy, 52(2), 96-107. https://doi-org.db.ub.oru.se/10.1598/JAAL.52.2.1

Norrby, C. (2014). Samtalsanalys: så gör vi när vi pratar med varandra. (3. uppdaterade uppl.) Lund: Studentlitteratur.

Nyberg, G., \& Meckbach, J. (2017). Exergames 'as a teacher' of movement education: Exploring knowing in moving when playing dance games in physical education. Physical Education and Sport Pedagogy, 22(1), 1-14. https://doi-org.db.ub.oru.se/10.1080/17408989.2015.1112778

Poveda, D., Cano, A., \& Palomares-Valera, M. (2005). Religious genres, entextualization and literacy in Gitano children. Language in Society, 34, 87-115. DOI: 10.10170S0047404505050049

Quennerstedt, M. (2006). Att lära sig hälsa. Örebro studies in Education 15. Örebro universitet.

Quennerstedt, M. (2013). Practical epistemologies in physical education practice, Sport, Education and Society, 18(3), 311-333. http://dx.doi.org/10.1080/13573322.2011.582245

Schleppegrell, M. J. (2004). The language of schooling: A functional linguistics perspective. Mahwah, NJ: Erlbaum.

Scollon, R., \& Scollon, S.W. (2004). Nexus Analysis: Discourse and the Emerging Internet. London: Routledge.

Shanahan, T., \& Shanahan, C. (2008). Teaching disciplinary literacy to adolescents: Rethinking content area literacy. Harvard Education Review, 78, 40-59.

Shanahan, T., \& Shanahan, C. (2012). What Is Disciplinary Literacy and Why Does It Matter? Topics in Language Disorders, 32(1), 7-18.

Street, B. (2000). Literacy events and literacy practices. In M. Martin-Jones, \& K. Jones (Ed.), Multilingual literacies: Comparative perspectives on research and practice (s. 17-29). Amsterdam: John Benjamin.

Svensson, G. (2013). "Who owns the words? Teaching vocabulary in a multicultural class." Education Inquiry, $4(2), 261-278$.

Svensson, T. (2014). Alexander, Sara och skriften: en skriftbruksetnografisk studie av barn i mellanåren. Diss. Örebro : Örebro universitet, 2014. Örebro.

Säljö, R. (2000). Lärande i praktiken. Ett sociokulturellt perspektiv. Stockholm: Prisma.

Tholin, J. (2006). Att kunna klara sig i ökänd natur. En studie av betyg och betygskriterier - historiska betingelser och implementering av ett nytt system. Högskolan i Borås.

Tolgfors, B. (2017). Bedömning för vilket lärande?: En studie av vad bedömning för lärande blir och gör $i$ ämnet idrott och hälsa. Örebro Studies in Sport Sciences, 2017.

Wenger, E. (1998). Communities of Practice. Learning Meaning and Identity (sixth ed.). Cambridge University Press, Cambridge.

Whitehead, M. (2007). Physical Literacy: Philosophical Considerations in Relation to Developing a Sense of Self, Universality and Propositional Knowledge. Sports Ethics and Philosophy, 1(3), 281-298. https://doiorg.db.ub.oru.se/10.1080/17511320701676916

Wickens, C. M., Manderino, M., Parker, J., \& Jung, J. (2015). Habits of Practice. Fournal of Adolescent E Adult Literacy, 59(1), 75-82. doi: 10.1002/jaal.429

Åkerfeldt, A. (2014). Didaktisk design med digitala resurser [Elektronisk resurs]: En studie av kunskapsrepresentationer $i$ en digitaliserad skola. Diss. (sammanfattning) Stockholm: Stockholms universitet, 2014. Stockholm. 